\title{
Fight back against segregation: the problem of 'two schools under one roof'
}

\author{
Lucha contra la segregación: el problema de las "dos escuelas bajo el mismo techo"
}

Sarina Bakić

University of Sarajevo - Bosnia and Herzegovina

Sarajevo, Bosnia and Herzegovina

sarina.bakic@fpn.unsa.ba

Nermina Mujagić

University of Sarajevo - Bosnia and Herzegovina

Sarajevo, Bosnia and Herzegovina

nermina.mujagic@fpn.unsa.ba

\section{ABSTRACT}

Authors analyse and conceptually problematise specific phenomena of 'two schools under one roof' in Bosnia and Herzegovina. They argue that education in Bosnia and Herzegovina has been routinely exposed to various, contradicting demands and pressures, which result in, among other contradictions, 'two schools under one roof', which presents one of the world's phenomenon within education. The authors are eager to present this specific education issue to the global public and provide some answers on various consequences, which appeared in this contemporary segregation form in Bosnia and Herzegovina. One of the significant objectives is to underline the concept in which education should be a human practice of cognition that is not determined by ideological currents. Furthermore, authors using several sociological and political science aspects regarding education, in general, will investigate and enlighten this specific phenomenon of segregation that is unique not only in the local but in the global context as well. The main objective of this article will be to present viable solutions on how 'two schools under one roof' can be altered or even abolished. institutions.

Keywords: autonomy, Bosnia and Herzegovina, 'two schools under one roof', ethnopolitics, education,

\section{RESUMEN}

Las autoras analizan y problematizan conceptualmente los fenómenos específicos de "dos escuelas bajo el mismo techo" en Bosnia y Herzegovina. Sostienen que la educación en Bosnia y Herzegovina se ha visto expuesta de forma rutinaria a diversas demandas y presiones contradictorias, que dan lugar, entre otras contradicciones, a "dos escuelas bajo un mismo techo", lo que representa uno de los fenómenos mundiales dentro de la educación. Las autoras desean presentar este problema educativo específico al público mundial y ofrecer algunas respuestas sobre las diversas consecuencias que ha tenido esta forma de segregación contemporánea en Bosnia y Herzegovina. Uno de los objetivos significativos es subrayar el concepto en el que la educación debe ser una práctica humana de la cognición que no está determinada por las corrientes ideológicas. Además, las autoras, utilizando varios aspectos sociológicos y de ciencias políticas relativos a la educación, en general, investigarán e iluminarán este fenómeno específico de segregación que es único no sólo en el contexto local sino también en el global. El objetivo principal de este artículo será presentar soluciones viables sobre cómo se pueden modificar o incluso abolir las "dos escuelas bajo el mismo techo".

Palabras clave: autonomía, Bosnia y Herzegovina, “dos escuelas bajo el mismo techo", etnopolítica, educación, instituciones. 


\section{INTRODUCTION}

Elementary and secondary schools that are functioning on the principle of 'two schools under one roof' are one of the challenges Bosnia and Herzegovina's educational system is facing. For over 25 years various levels of governance in Bosnia and Herzegovina are still hiding this specific issue "under the carpet". It is important to bear in mind that Bosnia and Herzegovina are one of the rare countries in the entire world having apartheid, the legal system which labels and separates children based on their national and religious identity. For every democratic country, this system is unacceptable and inappropriate. Bearing in mind the fact that this segregation system in education is a consequence of the state and political system of Bosnia and Herzegovina, which is created by Dayton Peace Agreement (1995). This international peace accord provided the Constitution (Annex 4) according to the state remained without sovereignty in the domain of education. Constitutional deficiency on education has provided to political elites and easier manipulation in the educational system towards children and their parents as well. Unfortunately, three ethnic education systems that resulted in the war (Bosniak, Croat, Serb), today are in the responsibilities between the state, entities, and cantons. Small administrative units on the entities, cantonal, and municipality level make Bosnia and Hercegovina's education the most expensive and the worst one in the entire world. Some research points out the lack of adequate education policies, lack of pupils and teacher's mobility, and the lack of quality legalization on the state level (Kreso, 2004). Radical politization of education and education that is not connected with the recovery of post-war economics have positioned Bosnia and Herzegovina's society in the line of those without a vision and clear directions for future development. Moreover, the political instrumentalization of education, the concept we are dealing with in this article, has prevented Intercultural dialogue, Intercultural understanding, and re-consolidation in general. Moreover, ethnically conceptualized education has a crucial role in maintaining strong ethnic homogenization and preservation of pure ethnic, national, and cultural borders.

For explanation and analysis, the principle 'two schools under one roof' we used documents of the Working Group for two schools under one roof and the OSCE report. Although there are many other analyses and reports on this matter, this Report was important to us due to its value judgment, which is corresponding to the opinions of these authors. Other analyses and reports deal with this Issue In a more descriptive manner. Working Group's report was written in April 2009 and finalized in February 2010 defining this term as: "The term 'two schools under one roof' means a school building in which two or more schools of the same or different levels of primary or secondary education are located as separate legal units, founded by municipalities or cantons, which are working according to curricula for the same or different level of education and they teach in the different languages of the constituent people".

According to the OSCE mission in Bosnia and Herzegovina reports, there are in total fifty-six primary and secondary schools in Bosnia and Herzegovina in twenty-eight locations that use this principle. During the ninety's war in Bosnia and Herzegovina, apart from the direct impact on education by destroying school infrastructure, ethnonationalism policies have also intervened in schools as well. The names of the schools changed, and religious symbols began to stand out. In the past years, it has become clear that education is one of the most important national interests and has an immense role in citizens and peace in this country. The war has ended (Dayton Peace Agreement 1995) but ethnic divisions and conflicts are still running. Political elites of this country are using schools as their battlefields and promoting intolerance between different national groups (Bosniaks, Serb, Croats) in Bosnia and Herzegovina.

Paraphrasing Smyth, education globally is currently experiencing 'difficult times' as their work is assaulted, prevailed upon, reformed, and restructured almost beyond recognition by forces bent upon decentralization, marketisation, de-professionalisation, and intensification (Smyth, 1998). All these are impacts of economic and political considerations that governments are placing on the importance 
of the roles of education and schools in society. This expressly refers to the context of Bosnia and Herzegovina, where almost all aspects of life are linked to politics, attacking education.

The objective of this article is to investigate concrete aspects of serious political pressures conceptualized on the ethnic and religious Identities that are encircling education in Bosnia and Herzegovina's society. Firstly, on the local level, it is about political demands and conditions within education. For example, political elites are in charge to elect managers of the schools and complete school staff. Furthermore, on the other hand, in the national context, it is about the burden, which originates in the form of the international community's expectation that this phenomenon should not be abolished even if it is strengthening only ethnic-national identities, which means exclusion, isolation, and indoctrination of children, pupils in the name of ethnic languages and exclusive religion purity. In other words, 'two schools under one roof' represent serious consequences of the war in Bosnia and Herzegovina (19921995); Therefore, the international community "flirts" with the political elites by placing this issue in the status quo.

The role of education in the wider context of society's development displays the level of general development. One society speaks of itself by relation towards education, relation towards tangible values that are interacted in all aspects of living. That is why authors express their apprehension about grave consequences that these conditions will reflect upon the society, and what kind of human beings are being and will be produced by this current polarized education system.

Some of these questions and answers to them were the light motive for our article in the domain of exploring relations between education and its current surroundings in Bosnia and Herzegovina. Using as an example the phenomenon of 'two schools under one roof' in Bosnia and Herzegovina, we notice that some of the political interventions both local and international are clearly ideological, such as the political control of schools and education in Bosnia and Herzegovina.

\subsection{What is exactly a phenomenon of 'two schools under one roof'?}

The phenomenon of 'two schools under one roof' is a product of post Dayton Bosnia and Herzegovina, which is reflecting political divisions, and it is one of the mechanisms for establishing divisions into education and the whole society as well. The potential integration of these schools should not be imposed from the outside, but from the inside, where there is consensus, and there is no conflict in perception. Gradually this important interaction and this cooperation will happen if children learn, for example, English or physics in the same classroom. Doing things this way, children, parents, and teachers will realize that it is nonsense to use two entrances in the building and two curricula. It could be easily done, but there is no political will to do so. Education in Bosnia and Herzegovina is problematic and challenging because it leads to separation because of differences, but not to overcome them.

Two schools under one roof are the main problem in Bosnia and Herzegovina, and it is about the fact that school is always dominated by one ethnic or national majority. By separating children, we are separating ethnic and national groups. It would not be a problem if European values were taught in schools. Furthermore, parents are not protesting because they approve of learning traditional values and ideologies in schools. Two schools under one roof are an indicator of the general condition, and the problem cannot be solved by closing schools. To solve the problem, it is necessary to free people from the national ideologies, to return to the civil culture, where people are not marked by their names and religion. Additionally, to this, the problem of 'two schools under one roof' overshadows the real problem, the crucial impact of nationalism on education transferring it to the entire society with enormous consequences.

After the war in Bosnia and Herzegovina (1992-1995), thousands of refugees were returning to their homes, but their children were prevented from going to schools, and that problem was attempted to be solved by local authorities who had an aim to prevent reintegration of the returnees into the 
community. At that time, parents were sending their children to ad hoc schools in accordance with their ethnic principles, which often did not have adequate conditions (they were in restaurants, houses, and bars). For example, in Usora, near Tešanj ( Zenica-Doboj Canton), in the local schoolyard, the school in the tent was made for Croatian children. In response to this problem, the international community with the Office of the High Representative initiated negotiations in local communities to help with giving the educational needs to the children who have their education in schools mentioned above. Agreements reached in local communities resulted in establishing 'two schools under one roof' as a temporary solution aimed at building trust in local communities. These schools work using their own curricula, they have some or different levels of primary or secondary education, and they teach in different languages of the constituent people of Bosnia and Herzegovina (Bosniaks, Serbs, Croats). The temporary solution aimed at building trust in local communities became permanent. In 2002, an agreement on meeting the needs and rights of children-returnees was signed. This agreement provided the curricula for the "national group of subjects" (such as history, language, geography) for children-returnees at the request of the parents. After the agreement, more than 33.000 children were enrolled in schools and more than 1800 teachers' returnees got a job. The returned children had the opportunity to learn a "national group of subjects" without having to travel to different cities, which was the only way to learn a national group of subjects before the agreement. This is supposed to be the first step in the school integration process. This principle clearly shows the situation in which Bosnia and Herzegovina find themselves, where children from different nations study in the same school building but have different curricula, are physically separated, and have different teachers. Students often use different entrances and have no chance to socialize. Physical separation occurs in schools in Herzegovina-Neretva Canton and Central Bosnia Canton, where all those schools have their part of the building, often very noticeable. The best example is the school in Travnik, where the schoolyard is divided by a metal fence. In these schools, they are teaching children that they are not as their peers, which is an attitude difficult to get rid of in the future.

In the Convention on the Rights of the Child it is written that education is "The preparation of the child for responsible life in a free society, in the spirit of understanding, peace, tolerance, equality of sexes, and friendship among all people, ethnic, national and religious groups and people of indigenous origin". One of the main arguments that politicians in Bosnia and Herzegovina are using when talking about this problem, and child returnees' parents are believing in it, is that solving this problem could lead to a weakening of ethnonational identity. It is not in the interest of politicians to solve this problem because they are using the situation to get votes. Also, they are saying that these schools would not be able to function if they haven't had the returner's support. The opposite of that, children returnees' parents say that they have no alternative solution. One of our main statements is that people in Bosnia and Herzegovina have much in common, instead of emphasizing that common constant, we are emphasizing differences. There is no principal problem in language, considering that all people can perfectly understand each other in Banja Luka, Sarajevo, and Široki Brijeg.

Correspondingly, we can view this problem from an additional perspective. We have an example of two schools under one roof in Sarajevo, Tuzla and Banja Luka too. The situation where parents in small cities are sending their children to this kind of school is not different from the situation where Croats in Sarajevo are sending their children to Catholic School Centre Sarajevo, and Bosniaks send their children to the First Bosniak Gymnasium. It is almost the same. Doing things this way, we are teaching our children that only people worthy of respect are people from the same ethnic and religious group they belong to, and all others should be ignored and even destroyed. The main problem is that in Bosnia and Herzegovina three different curricula are exciting, and people can choose which one they want for their children while nobody is doing anything to find common grounds. 


\section{METHODS}

Our main methodology is an analysis of content and comparative methods, primarily, OSCE BiH Report. The reason we have decided to use OSCE BiH Report is clear because the question of educational reform in Bosnia and Herzegovina has been initiated by the international community, where the OSCE BiH holds a key role. Especially in the matter of 'two schools under one roof'. In 2000, OSCE BIH formed the Commission for Textbooks for Elementary Schools that overview textbooks of national subjects' group and eliminated 'inappropriate' contents. Analyses of OSCE Report additionally mean that this problem is viewed globally as well. To create a further investigation of this significant segregation problem in education, we have used methods of analyses and synthesis. The methodology is used to show that we are talking about a direct violation of children's rights and human rights in general.

\section{RESULTS}

\section{1 'The closing of the Bosnian Mind'}

The crisis in education that is 'talk of the talk' in the recent period is basically an expression of a larger crisis known as "Die geistige Situation der Zeit" (Jaspers, 1987) in which we are all living in. Moreover, difficulties regarding the determination of the role of education in society represent the consequences of re-examining the general values system within scientific and technical civilization today. Civilization in question is already in an entirely new phase dominated by information and digital technology in general, which perspectives and scopes cannot be foreseen yet. This new paradigm is not a problem itself, but it is about their implementations, understandings, and creation of relation towards the world and humankind as well. This is possible only by returning to the humanistic principles of education in general, which means directing the knowledge towards all-purpose wellbeing for the entire society and not only for personal, professional, and nationalistic benefits.

It also reflects the position of education in an extremely specific social and political context such as in Bosnian and Herzegovina. The General Framework for Peace in Bosnia and Herzegovina (known as the Dayton Peace Agreement) signed in 1995 does not refer particularly to the issues of education, especially not to the issues of two schools under one roof. Article 2 of Annex 4 of the Dayton Peace Agreement (The Constitution of Bosnia and Herzegovina) provides the right to education among other fundamental rights and freedoms. Among the scarce responsibilities of the institutions of Bosnia and Herzegovina, the jurisdiction over education and scientific research cannot be found. The entire situation with education is complex and ambiguous. According to the Dayton Peace Agreement, the jurisdiction over education is fragmented into 12 various political agents. In one of the two entities of Bosnia and Herzegovina, Republika Srpska, education is highly centralized on the entity level, while in another entity, the Federation of Bosnia and Herzegovina, it is highly decentralized and distributed among its 10 cantons according to the Washington Agreement of 1994. Although there exists the Ministry of Education on the Federation Entity level, its role in matters of education is rather honorary. Furthermore, after the completion of the arbitration process for the disputed area of Brčko in 2000, this unique self-governed local multi-ethnic unit of Bosnia and Herzegovina was also awarded jurisdiction over education in general. In the end, 12 various political agents, or entities, are entitled to the jurisdiction over education and to articulate and implement independent education policy.

On the other hand, the relation between global society and education, together with various processes within the education sphere is the main issue undertaking the reformation of education. The main question coming out from the reassessment of these specific relations is in what way these contemporary processes and practices in education reflect on the position and perspective of everyone within the society. 
Relations that are already mentioned are mostly researched and considered within two key and opposed theories (Koković 1992, p. 5). Firstly, theoretical orientation according to which education represents explicitly the reproduction mechanism of already existing social and political structures. Secondly, it is a theory that accentuates an ability for education to form a new type of society, according to what education is the significant factor for the reformation of contemporary societies and the main societies' structural issue as well (Bauman, 2011). Regarding the concept of education as a structural problem, it is recognised that there has been a parting between knowledge and reality or social actuality, learning and production together with a parting between values and social positions. In other words, it is simply about society's dissections on areas where knowledge is created and areas where knowledge is produced (Ball, 2006, p. 81) within the contemporary footings mentioned already above.

The first theory finds its fundamental base within social conditions in which a specific educational system appears. Thus, it cannot be perceived without follow-up and analyses of changes and circumstances regarding specific society. It means that in this case society implies educational aims and circumstances in which education produces, conditioning fluctuations and models of changes in order to preserve the existing social and political system. On the contrary, the second theoretical opinion refers to a possibility for education to become less dependable on primarily political and various ideological influences.

Out of this short elucidation, it is more than apparent that in the context of a contemporary examination of education in Bosnia and Herzegovina, both of these theoretical approaches cannot be completely suitable and satisfactory. Namely, each reform in education and each reform within society have their strong existence regardless of their planning, directing, and assessing. Subsequently, many of these processes are achieved partially followed by numerous discrepancies and illogicality as well. This can be specially referred to as the education reforms in Bosnia and Herzegovina. For example, the inclusion of a greater number of young people in education should have basically strengthened democratization processes in the whole society and decreased social inequalities followed up by the development of intercultural dialogue and reconciliation processes. Nevertheless, expansion of education in the quantitative context resulted in cementing and further production of social, political, and cultural inequalities. On the other hand, tackling the global framework as well, after the war generations in Bosnia and Herzegovina divided by various identities as well are facing the prospect of "downward mobility" (Bauman, 2011, p. 30). According to Bauman, their parents "were trained to expect, matter-offactly, that children will aim higher and reach further than themselves managed (or had been allowed by the new bygone state of affairs) to dare and achieve: they expected the intergenerational "reproduction of success" to go on beating their own records as easily as they themselves used to overtake the achievement of their parents" (Bauman, 2011, p. 30-31). Many elders expect that their children will have wider appealing choices, climb higher in the social structures, be wealthier and far more successful than them and others. But we cannot say who prepared these young people for "the arrival of the hard, uninviting and inhospitable new world of downgrading of grades, devaluation of earned merits, doors shown and locked, the volatility of jobs and stubbornness of joblessness, the transience of prospects and durability of defeats" (Bauman, 2011, p. 33). At least it was only supposed that somebody or something was preparing them for these various challenges.

Right now, it is difficult to conclude which of these two concrete aspects is causing larger damage for the society of Bosnia and Herzegovina. Rephrasing Zygmunt Bauman (2011), these phenomenon 'two schools under one roof' together, appearing at the same time, can make quite an explosive combination. Moreover, this education becomes 'powerful instruments" (Foucault) of the national modern state.

Nonetheless, inadequate and rather sluggish progress in the education field together with the overall worried quality of life in Bosnia and Herzegovina obviously directs towards theoretical views that are mostly connected with an adjustable function of education via requirements of ruling political and cultural ideologies. In the sociological context, difficulties are not found only in existing various ideological loads and impacts or different political preferences. It is about still inadequate confrontation 
with consequences of war, poverty, and unemployment of many citizens in Bosnia and Herzegovina, economic and cultural trailing, illiteracy and fear of the others and different ones, which are products of 'two schools under one roof'. This type of ambient, artificially created and maintained, additionally confounds already complex educational system(s).

It is important to underline that anomalies in question are not 'reserved' only for the education sphere. They are influencing and destroying many aspects of life, tackling at the same time individuals and various social groups in Bosnia and Herzegovina.

Using politicization of ethnic and religious identities as one of the most important aims of national political parties in Bosnia and Herzegovina created out of this country a unique, specific, outrageous, modern form of apartheid today in contemporary Europe and the world. In the current context, an issue of humanistic education and humanization in general, according to Freire (1970) is not anymore just a basic question of human beings from the philosophical aspect, but it has already been an issue of unavoidable concern and a serious problem for a decade already.

Discussions on the 'education' missions have resulted in the pluralism of approaches and opinions about the role of education in modern societies. For example, in his well-known book The Closing of the American Mind, Allan Bloom states openly that "every educational system has a moral goal that it tries to attain and that informs its curriculum". It wants to produce a certain kind of human being" (Bloom, 1987, p.26). In this way, Bloom straightforwardly determines the institution of education as one of the 'ideological state apparatus designed to reproduce conditions of ideology's hegemony, that is, "the reproduction of the conditions of production" (Althusser, 2008, p. 1) of a dominant ideology. Bloom even adds that, in fact, it is the political regime that matters, and this regime requires its „citizens who are in accord with its fundamental principles"(Bloom, 1987, p.26). So, our question is: "what kind of human beings, or citizens, are being produced by the present segregating educational system in Bosnia and Herzegovina, which as a result carries out the phenomenon of 'two schools under one roof'? It is our indication, however, that the educational system of this country, in the variety of its ethnonationalism forms, is redesigned to produce, let us paraphrase Bloom here, 'men and women who have tastes, bits of knowledge, and character supportive of an ethnonationalist regime'.

\subsection{Political system as nesting spot for two schools under one roof}

Institutions that have jurisdiction' for educational reform have an obligation to eliminate existing discrimination practice, and their actions are directed in that way. Having 'two schools under one roof' represents a violation of international conventions and domestic law. Judgments in this field are not implemented. Having 'two schools under one roof' complicates the economic progress as well. Money is being spent on maintaining this system but not on improving the teaching process, teacher training, school supplies, school infrastructure, and the teaching process in general. Closing these schools would endanger the financial existence of several teachers and administrative staff. In addition, there is a lack of political will, both due to political issues and the personal interests of political parties, but also due to the concerns of parents regarding the preservation of national identity. Progress on this issue is only possible if the political authorities in Bosnia and Herzegovina identify the problem and take responsibility for further steps. But why would they act when they create their machinery in this way? The problem of 'two schools under one roof' should have been solved earlier because now we are all unfortunately used to it. Everyone lives in their own sheepfold, and we are safest where ours are. When asked if the children who attend these schools have meetings and if they socialize after school, one

$1 \quad$ The Federation of Bosnia and Herzegovina is decentralized and contains ten Cantons. It was created based on Washington agreement from 1994. The jurisdiction in the field of education in Federation of Bosnia and Herzegovina was given to the cantons, which fact was confirmed by the Constitution of the Federation of Bosnia and Herzegovina. In the section III the Constitution is regulating the division of jurisdiction between Federal and Cantonal government. In the article $4 \mathrm{~b}$ Cantonal jurisdictions are regulated and it is written "Making education policy, including decisions concerning the regulation and provision of education". Federal Ministry of education has not active role in the field of education and has no instruments for administrative control. 
teacher says: In most cases not. Some catalyst is needed for that to happen. "The moment you allow them to do that, they have meetings, otherwise, it doesn't happen because it is known exactly where the cafe is".

The segregated education system in Bosnia and Herzegovina is visible through the already highlighted phenomena of "two schools under the same roof" and through three separate curricula for three ethnic groups ${ }^{2}$. According to the book Education in Bosnia and Herzegovina: What are we (not) teaching our children (2017): analyses of the national group of subject's handbooks' content in elementary schools in Bosnia and Herzegovina prove that only $7 \%$ of lesson units promote universal human values together with peace and love as on the last position of the scale. The practice of 'two schools under one roof' violates various international conventions as well as legislation in Bosnia and Herzegovina. For example, court decisions found the practice of 'two schools under one roof' in Stolac and Čapljina discriminatory, but this court decision is still not implemented.

A positive step forward is the administrative and legal unification of the two schools under one roof in some locations. This means that two schools located in the same location become one legal entity with one name, a single board, budget, principal, and a deputy (both members of different nations), one teacher's council, one parent's council, and one student's council. A good example is a school in Žepče, which was formed in 2004 and was created by the administrative and legal unification of the Secondary Mixed School and the Mixed Secondary School. This school has both Bosnian and Croatian curricula, but it is positive that they have a common entrance, joint professional and extracurricular activities and the same teaching staff and they work in the same shift, so the interaction of all students at this school is possible. There are many obstacles to ending this practice and some of them are political obstructions related to the preservation of national identity. An alternative to these schools is inclusive schools in which students will attend as many classes as possible together. Linguistic and cultural differences would be respected through attendance at separate language and religious education classes. Students should learn from curricula that promote tolerance and critical thinking in which students are offered multiple perspectives.

So, back to Bloom's question - what kind of citizens does such a system of education tend to produce? 'Bosnian pattern', it seems, fits in general trends of the systematic political undermining of education. In the book Unpleasant Guest: Nihilism and Youth, an Italian philosopher of history and dynamic psychology Umberto Galimberti claims that "education systems are barren and powerless, families frightened to indifference, only heritage unreliable, science and religion, each with their bankruptcy lost credibility..." (Galimberti, 2013, p. 224). In his opinion, it is not a question of the usual existential crises because there are still wars in the world or because human rights are not respected. All around us, everything is nihilism, an unpleasant visitor that "penetrates our feelings, blurs our thoughts, erases our perspectives and horizons, weakens our souls, corrupts our passions, making them bloodless" (Galimberti, 2013, p. 17), and produces hard times for everyone. This type of discomfort is no longer psychological but cultural, a problem in society, and solutions should be sought on a collective level, especially in educational systems that do not create a compassionate culture and do not sensitize young people to empathize with others, putting themselves in the position of another. This type of educational system in Bosnia and Herzegovina does not contribute to the strengthening of universal values, especially the strengthening of reconciliation and strengthening of the peace processes in a country that greatly needs it.

Education will certainly not correct the injustices and social inequality that are before our eyes. Moreover, it often, especially in Bosnia and Herzegovina, reflects the multitude of social injustices and inequalities in the country because it is fragmented along ethnic lines; competencies of education are

$2 \quad$ It is also reflected through relation towards minorities, especially to Roma people. Progress Report from 2017 regarding Bosnia and Herzegovina's accession to EU states that there is no single progress regarding status of Roma people, their language, culture and history. There is no school in Bosnia and Herzegovina, which offers Roma language as subject nor any other alternative in this matter. 
at the level of cantons, the phenomenon of 'two schools under one roof' is a given in everyday life, people's habits, everyday communication, and mutual living.

This sphere of extreme political importance reserved for the institution of education in the Dayton Bosnia and Herzegovina too often contributed to the fact that extreme discriminatory practices and violations of fundamental human rights and freedoms - one of the worst being literally physical separation of pupils according to their ethnic background in ethnically 'mixed' schools in some cantons of the Federation Entity - have been tolerated not only by domestic but also by the international institutions present in Bosnia and Herzegovina. The so-called 'two schools under one roof' are a staggering example of legal discrimination 'justified' by human rights arguments.

\section{CONCLUSION}

Segregation in education in Bosnia and Herzegovina is one of the crucial problems for the reconciliation and integration processes of this compound society in general. According to all the above-mentioned observations, when speaking about the phenomenon of 'two schools under one roof', we can claim that there is an immediate need for a huge reversal in the education field followed by the honest question where exactly we are heading as a society and by deeper conviction about what kind of people we are supposed to be. In the atmosphere of the long-term systematic destruction of the education system, mainly from the aspect of political influence and political interference in the education system(s) in general, we can conclude that the crisis in this vital social segment is the most dangerous part of the general crisis within Bosnia and Herzegovina's context.

In addition, the orientations of this framework continue to depend on all structures of the state and the international community, which are the conditions for modernization, professionalization, and universalization of education in Bosnia and Herzegovina. Torn apart between various 'truths', histories and identity issues, lack of political consensus in almost all imperative matters, we have anticipated numerous hard challenges and obstacles that are preventing affirmative solutions within this vital aspect of society such as education. By integration of the education system in Bosnia and Herzegovina and implementation of universal standards, human rights will be respected, as it is proclaimed within the General Declaration of Human Rights.

More, concretely, our aim was to provide an answer to the inherent question on what kind of human beings, or citizens, are being produced by the current educational system in Bosnia and Herzegovina referring to the strong example of 'two schools under one roof'. The 'product' that we reflect on in this $t$ in this article are individuals and social groups, in the variation of its ethnic and religious forms, that would continuously support and 'feed' ethnonationalism patterns, expanding nationalistic political correctness as mainstream cultural scenery together with an absolute lack of sensitivity for overall well being followed by an absence of understanding towards different ones and others.

Analyses in this article lead us to the conclusion that still an ongoing phenomenon of 'two schools under one roof', which constantly environs education in Bosnia and Herzegovina, contributes to the further disintegration of the entire society, with devastating consequences in the future for unquestionably everyone in Bosnia and Herzegovina. Therefore, we are recommending further research about this important issue and unique example of segregation in education within the entire world. Without major changes in this educational system, it will not be possible for children in Bosnia and Herzegovina to grow up together without isolation as children in the entire world have the true right to do so. 


\section{REFERENCES}

Althusser, L. (2008). On Ideology. Verso.

Ball, S. (2006). Education Policy and Social Class, The Selected Works of Stephen J. Ball. Routledge.

Bauman, Z. (2011). Liquid modern challenges to education. Padova University Press Università degli Studi di Padova.

Bloom, A. (1987). The Closing of the American Mind. Simon \& Schuster.

Convention on the Rights of the Child available at: https://www.unicef.org/child-rights-convention/convention-text Freire, P. (1970). The Pedagogy of the Oppressed.The Continuum International Publishing Group

Galimberti, U. (2013). Nihilism and Youth. Bosansko narodno pozorište Zenica i Pedagoški fakultet, Univerzitet u Zenici. Jaspers, K. (1987). The Spiritual Situation of the Time. Književna zajednica Novog Sada.

Koković, D. (1992). Sociology of Education. Matica Srpska.

Open Society Fund BiH and ProMENTE (2017). Education in Bosnia and Herzegovina: What are we (not) teaching our children: analyses of national group of subject's handbooks'. Mas Media Sarajevo. Open Society Fond Bosnia and Herzegovina.

OSCE Mission to Bosnia and Herzegovina (2018) "Two Schools Under One Roof" The Most Visible Example of Discrimination in Education in Bosnia and Herzegovina. OSCE Mission to Bosnia and Herzegovina.

Pašalić-Kreso, A. (2004). Constitution and Education in Bosnia and Herzegovina. Open Society Bosnia and Hercegovina Smyth, J. (1998). Developing and sustaining critical reflection in teacher education. Journal of teacher education 40(2), 2-9. https://doi.org/10.1177/002248718904000202

\section{AUTHORS}

Sarina Bakić. Sociology of art and culture, sociology of everyday life, art and politics, mass culture phenomena.

Nermina Mujagić. Expert In political communication., political theories, post-conflict, media.

\section{Conflict of interest}

No potential conflict of interest is reported by the authos.

\section{Funding}

No financial assistance from parties outside this article.

\section{Acknowledgments}

$\mathrm{N} / \mathrm{A}$ 